Illinois State University

ISU ReD: Research and eData

Theses and Dissertations

$7-5-2014$

\title{
Assessing Students' Attitudes Towards Geography in a Problem- Based Learning Environment
}

Andrew Jasper Quain

Illinois State University, andrew.quain@gmail.com

Follow this and additional works at: https://ir.library.illinoisstate.edu/etd

Part of the Education Commons, and the Geography Commons

\section{Recommended Citation}

Quain, Andrew Jasper, "Assessing Students' Attitudes Towards Geography in a Problem-Based Learning Environment" (2014). Theses and Dissertations. 215.

https://ir.library.illinoisstate.edu/etd/215

This Thesis is brought to you for free and open access by ISU ReD: Research and eData. It has been accepted for inclusion in Theses and Dissertations by an authorized administrator of ISU ReD: Research and eData. For more information, please contact ISUReD@ilstu.edu. 


\title{
ASSESSING STUDENTS’ ATTITUDES TOWARDS GEOGRAPHY \\ IN A PROBLEM-BASED LEARNING \\ ENVIRONMENT
}

\author{
Andrew J. Quain
}

43 Pages

August 2014

Problem-based learning is a strategy used increasingly in geographic classrooms at all levels. The benefits of problem-based learning and how it improves students' content knowledge are well established in the literature. However, a gap in the literature exists in regards to the impact problem-based learning has on students' attitudes towards geography. This study focused on determining if high school students' attitudes towards geography improved after enrollment in a course taught with problem-based learning instruction. The study assessed other factors, such as preference for group work and problem-solving efficacy, which are associated with problem-based learning instruction. The research found no differences in students' attitudes towards geography, preference for group work, and problem-solving efficacy after their experiencing a course taught with problem-based learning instruction from the attitudes that students expressed before the learning experience. Possible causes for the absent change in attitudes are explored and suggestions for future studies are provided. 


\section{ASSESSING STUDENTS’ ATTITUDES TOWARDS GEOGRAPHY \\ IN A PROBLEM-BASED LEARNING \\ ENVIRONMENT}

ANDREW J. QUAIN

A Thesis Submitted in Partial

Fulfillment of the Requirements

for the Degree of

MASTER OF SCIENCE

School of Teaching and Learning

ILLINOIS STATE UNIVERSITY

2014 
ASSESSING STUDENTS’ ATTITUDES TOWARDS GEOGRAPHY

IN A PROBLEM-BASED LEARNING

ENVIRONMENT

ANDREW J. QUAIN

COMMITTEE MEMBERS:

Thomas A. Lucey, Chair

Douglas D. Hatch

Gary A. Weilbacher 


\section{CONTENTS}

CONTENTS

TABLES

CHAPTER

I. THE PROBLEM AND ITS BACKGROUND

Background to the Study

Problem-Based Learning

Students' Attitudes Towards Geography

Statement of the Problem

II. REVIEW OF RELATED LITERATURE 6

$\begin{array}{ll}\text { Introduction } & 6\end{array}$

$\begin{array}{ll}\text { Problem-Based Learning } & 7\end{array}$

Problem-Based Learning in Geographic Education 8

Students' Attitudes Towards Geographic Education 10

Group Work and Problem-Solving Efficacy 12

Research Questions

III. METHODOLOGY 14

$\begin{array}{ll}\text { Introduction } & 14\end{array}$

$\begin{array}{ll}\text { Sample } & 14\end{array}$

$\begin{array}{ll}\text { Instrumentation } & 15\end{array}$

$\begin{array}{ll}\text { Procedure } & 17\end{array}$

$\begin{array}{ll}\text { Analysis } & 19\end{array}$

IV. RESULTS 21

Question 1: Does the Introduction of

Problem-based Learning Positively Improve

High school Students' Attitudes towards Geography? 21

Ancillary Analysis 
Question 2: Does the Introduction of

Problem-based Learning Positively Improve

High school Students' Preferences towards

Working in a Group?

Question 3: Does the Introduction of

Problem-based Learning Positively Improve

High school Students' Problem-solving Efficacy?

Question 4: Is there a Correlational Relationship

Between High school Students' Attitudes towards

Geography and Preference for Working in Groups

after Problem-based Learning Instruction?

Question 5: Is there a Correlational Relationship

Between High school Students' Attitudes towards

Geography and Problem-solving Efficacy after

Problem-based Learning Instruction?

V. DISCUSSION

Introduction

Patterns of Learning in Schools

Lack of Geographic Education

Limitations

VI. CONCLUSION

Conclusion and Implications

Recommendations for Future Research

REFERENCES

APPENDIX A: Participant Survey

APPENDIX B: Table 9: Significance of Change in Subscales of Students' Attitudes

Towards Geography 


\section{TABLES}

Table Page

1. Students' Attitudes Towards Geography 22

2. Significance of Change in Students' Attitudes Towards Geography

3. Subscales of Students' Attitudes Towards Geography

4. Students' Preference Towards Group Work

5. Students' Problem Solving Efficacy

6. Significance of Change in Students' Problem Solving Efficacy

7. Relationship Between Students' Geographic Attitudes and Preference for Group Work

8. Relationship Between Students' Geographic Attitudes and Problem Solving Efficacy 


\section{CHAPTER I}

\section{THE PROBLEM AND ITS BACKGROUND \\ Background to the Study}

When the newly created Common Core State Standards for English-Language Arts and Mathematics went into effect, expectations for students to begin thinking at higher levels increased immensely (Council of Chief State School Officer and National Governors Association, 2010). Unlike No Child Left Behind 2001 which forced schools to focus attention and curriculum to tested material (Mitchell, 2009; Vogler \& Virtue, 2007), the Common Core State Standards have the opportunity to emphasize a more research centered, interdisciplinary approach (Council of Chief State School Officer and National Governors Association, 2010) than previous curriculum movements in order to prepare students for college and career readiness. The movement implies that social studies subjects have the potential to take a more important role in school curriculum because social studies teach content using the English-Language Arts and Mathematics skills. "By its very nature, geography is already interdisciplinary" (Spronken-Smith, 2005, p. 206) and therefore an effective course in preparing students for college and career readiness examinations.

Geography can be a useful interdisciplinary subject, however the passing of No Child Left Behind 2001 left geography and other social studies subjects off the "test", pushing them to the back burners of many schools' curricula. High stakes testing forces 
schools to focus attention and curriculum on tested material (Mitchell, 2009). Therefore the omission of social studies on the ACT and Prairie State Achievement Examination in the State of Illinois means less attention to geography education in the K-12 curriculum. No Child Left Behind created a high stakes, test guided curriculum rather than a curriculum that addresses the needs of students to live and adapt in a changing world (Vogler \& Virtue, 2007). With the creation of the Common Core Standards for EnglishLanguage Arts and Mathematics, there is an opportunity to include geography curriculum this time. Geography educators do not have to look very far for an instructional strategy to best embrace a student centered, interdisciplinary approach. Research shows the effectiveness of problem-based learning in geography classrooms (Brickell \& Herrington, 2006; Havorson \& Wescoat, 2002; Patterson, Reeve, \& Page, 2003; Tulloch \& Graff, 2007). "Problem-based learning is apprenticeship for real-life problem solving" (Stepien \& Gallagher, 1993, p. 25) and therefore, it can help bridge different subject matters (Drennon, 2005). Skills needed in geography problem-based learning instruction are the same skills outlined in Common Core Standards. For example, Mathematics skills are used while students collect and analyze population data and English skills are used when students present their findings.

\section{Problem-Based Learning}

Geography education has "strong traditions of small-group work, both through laboratory and field teaching, [and] is well placed to try such teaching methods as problem-based learning" (Spronken-Smith, 2005, p. 203). "In the problem-based [learning] approach, complex, real-world problems are used to motivate students to identify and research the concepts and principles they need to know to work through 
those problems" (Duch, Groh, \& Allen, 2001, p. 6). The majority of research done on problem-based learning in geographic education focuses on its effectiveness of improving content knowledge (Brickell \& Herrington, 2006; Havorson \& Wescoat, 2002; Patterson et al., 2003; Tulloch \& Graff, 2007).

\section{Students' Attitudes Towards Geography}

According to Walker (2006), students have higher achievement with subject matter when they are in a good mood, enjoy what they are doing, and have a positive attitude. Alvarez (1998) looked into the effect childhood spatial activities had on attitudes of high school geography students. Alvarez found no correlation between students' childhood spatial activities and their attitudes towards geography education at the secondary level. Alvarez's results failed to show how a teacher could positively affect students' attitudes towards geography when students do not have prior geography experience.

There is potential to create positive attitudes towards geographic learning. Research conducted outside the United States on students' attitudes towards geography showed that students did have a positive outlook towards geography (Aydin, 2011). Aydin (2011) used open response items to determine if high school students had positive attitudes towards geography in order to prepare future lesson plans that better suit students' needs. College studies that included students' attitude towards geography limited their attention on content knowledge rather than on attitudes (Havorson \& Wescoat, 2002; Spronken-Smith, 2005). Both Havorson and Wescoat (2002) and Spronken-Smith (2005) found that problem-based learning improved students' attitudes 
towards geography. All of these studies show positive outcomes in regards to students' geographic attitudes.

Other research showed students' geographic attitudes in relationship to the introduction of problem-based learning and technology or other web-based map-making tools (Baker \& White, 2003; Drennon, 2005; Keiper, 1999; Tulloch \& Graff, 2007). One of the most common pieces of technology used in geographic education is Geographic Information System (GIS) (Baker \& White, 2003; Bednarz, 2004; Keiper, 1999; Patterson et al., 2003; Shin, 2006; Songer, 2010). GIS, as defined by the National Research Council in Learning to Think Spatially (2006), is "integrated software systems for the handling of geospatial information: for its acquisition, editing, storage, transformation, analysis, visualization, and indeed, virtually any task that one might want to perform with this particular information type" (p. 159). GIS used in the classroom allows students to both collect spatial data, and analyze it through computer software. Improved student attitudes towards geography in Baker and White (2003), Drennon (2005), Keiper (1999), and Tulloch and Graff (2007) cannot be solely credited to problem-based learning instruction, but rather the idea that students enjoy the introduction of new technology.

\section{Statement of the Problem}

As schools adjust to the new Common Core State Standards and the discipline of geography incorporates new national standards, the opportunity for researching the instructional method of problem-based learning in geography was needed. Both the Common Core State Standards and the new National Geography standards emphasize student-focused curriculum (Council of Chief State School Officer and National 
Governors Association, 2010; Heffron \& Downs, 2012). Problem-based learning research represents a student-focused approach that is also an effective instructional strategy to improve geographic content knowledge (Brickell \& Herrington, 2006; Havorson \& Wescoat, 2002; Patterson et al., 2003; Tulloch \& Graff, 2007). However, a lack of research of the effects of problem-based learning on high school students' attitudes towards geography currently exists. The purpose of this study is to determine if the introduction of problem-based learning in a high school geography course affects students' attitudes towards geography. Since problem-based learning often uses group work and a high degree of problem solving, an additional purpose of this study is to determine if students' attitudes are affected by preference for group work or problemsolving efficacy. 


\section{CHAPTER II}

\section{REVIEW OF RELATED LITERATURE \\ Introduction}

The importance of social studies curriculum has been underappreciated due to the No Child Left Behind legislation and its omission from standardized tests (Mitchell, 2009). The creation of the Common Core State Standards provides an opportunity for non-tested school subjects, for example social studies, to assist in teaching skills tested in the subjects of Mathematics and English-Language Arts (Council of Chief State School Officer and National Governors Association, 2010). In order to accomplish this, a student-centered, interdisciplinary approach is needed in teaching social studies courses at the secondary level. A student-centered, interdisciplinary approach is needed because it allows the learning of multiple subjects at the same time.

Problem-based learning is an effective instructional strategy for improving student knowledge in various levels of geography (Baker \& White, 2003; Brickell \& Herrington, 2006; Havorson \& Wescoat, 2002; Keiper, 1999; Patterson et al., 2003; Tulloch \& Graff, 2007). This chapter examines the literature related to problem-based learning in geographic education, students' attitudes towards geography, preference for group work, and problem-solving efficacy. First, the chapter provides a background of problem-based learning and the roles teachers and students take in a problem-based 
learning environment. Second, the literature related to problem-based learning in geographic education is presented. Next, students' attitudes towards geography are discussed. Finally, the literature of students' problem-solving efficacy and preference for group work are explored as they related to this study. The chapter's conclusion provides a problem that was revealed from the literature along with the research questions created to examine that problem.

\section{Problem-Based Learning}

The instructional strategy, problem-based learning (PBL) allows students to solve realistic problems similar to those people outside of the classroom face everyday (Havorson \& Wescoat, 2002; Mergendoller, Maxwell, \& Bellisimo, 2006). The problems are "ill-structured," meaning that students will not know at first how to solve the problem. They will not have the information to solve the problem, and they will never know for sure if their solution is the best choice (Brickell \& Herrington, 2006; Havorson \& Wescoat, 2002; Stepien \& Gallagher, 1993). For example, students receive an assignment to plan a redevelopment of an old industrial park in their hometown. Students map the area; learn about hazardous waste, city zoning, urban development, and city politics. These types of problems go beyond teaching textbook content knowledge only, such as facts and dates; they teach problem solving skills (Brickell \& Herrington, 2006) and increase student interest and motivation (Mergendoller et al., 2006; Tulloch \& Graff, 2007).

In PBL classrooms students voice their feelings on issues (Tulloch \& Graff, 2007) and actively solve problems (Mergendoller et al., 2006; Stepien \& Gallagher, 1993). The teacher fulfills a much different role from industrial traditional lecture based teaching. In 
PBL, teachers serve as a facilitator, coach students and give suggestions, but not assigning daily-predetermined assignments (Mergendoller et al., 2006; Stepien \& Gallagher, 1993). Teachers must also model behavior they want students to use and serve as collaborators with students to help them problem solve (Stepien \& Gallagher, 1993). Students will learn from the problems they encounter and the community will serve as the textbook (Bednarz, 2004). The student must "read" the needs of their community to solve the problem.

The use of problem-based learning allows students to solve real-life problems that they face daily (Mergendoller et al., 2006; Stepien \& Gallagher, 1993). Jonassen (2000) found that students are not exposed to the types of problems they need to solve in real life. In the industrialist tradition model of teacher-centered classrooms, problems encountered by students typically have only one correct answer; while the ill-structured problems students face in problem-based learning instruction have multiple correct answers and multiple ways of getting those answers (Brickell \& Herrington, 2006). Problem-based learning instruction matches well with the needs of geography curriculum (Brickell \& Herrington, 2006; Havorson \& Wescoat, 2002; Patterson et al., 2003; Tulloch \& Graff, 2007). Geography curriculum requires students to look at local needs, then ask questions and answer them (Béneker, Sanders, Tani, Taylor, \& van der Vaart, 2007).

\section{Problem-Based Learning in Geographic Education}

Problem-based learning improves geographic content knowledge (Brickell \& Herrington, 2006; Havorson \& Wescoat, 2002; Patterson et al., 2003; Tulloch \& Graff, 2007). The implementation of problem-based learning instruction in geographic education frequently incorporates Geographic Information Systems technologies. A high 
school advanced placement geography class utilizing problem-based learning resulted in students scoring significantly higher on the same test given to college undergraduates in a similar class learning under the industrialist tradition of lecture (Patterson et al., 2003). Patterson, Reeve, and Page (2003) showed that problem-based learning with GIS improves academic achievement at younger ages. In geography classrooms, GIS is an effective tool to use with PBL instruction (Bednarz, 2004). GIS helps geography students think spatially (Tulloch \& Graff, 2007).

Problem-based learning instruction allows the teacher to create realistic, illstructured problems that students solve. Students rely on their prior knowledge to solve these problems. When setting up a geography curriculum, attention to students' own experiences especially pertaining to the environments in which they live must be considered (Béneker et al., 2007). Bradbeer, Healey, and Kneale (2004) found that a majority of U.S. students feel that learning comes through personal experiences. Problem-based learning allows students to use their prior knowledge. Geography standards help students understand their personal experiences throughout their lives (Bednarz et al., 1994). These standards need to be taught with the local setting kept in mind; activities, lectures, readings, and projects need to reflect the experiences that individual students have experienced or will experience. Problem-based learning instruction allows students to better understand more complex geographic ideas because students can relate it to their prior knowledge.

Geography educators have frequently incorporated Geographic Information Systems into problem-based learning instruction to improve critical thinking and specifically geographic thinking skills (Bednarz, 2004; Shin, 2006). By thinking 
geographically students will also start to ask questions about the world around them and then can use GIS to answer those geographic questions (Shin, 2006). GIS is a good tool for problem-based learning instruction because GIS is interactive, it helps students learn how to read maps (Shin, 2006).

\section{Students' Attitudes Towards Geographic Education}

Walker (2006) noticed little attention had been paid to the research of students' attitudes towards geography. Students have higher achievement with subject matter when they have a positive attitude towards the subject (Walker, 2006). Research conducted by Alvarez (1998), Havorson and Wescoat (2002), and Spronken-Smith (2005) only makes students' attitudes towards geography a minor subset of their research. Since students with positive attitudes towards the subject matter will have higher achievement (Walker, 2006), more research in this specific area needs to be completed. This is why Walker (2006) developed a valid test, Test of Geography-Related Attitudes (ToGRA), to find students' attitudes towards geography education (Walker, 2006).

Prior to Walker (2006), literature on students' geographic attitudes included studies by Alvarez (1998), Havorson and Wescoat (2002), and Spronken-Smith (2005). Alvarez (1998) created a test to determine if high school geography students' childhood (age 3-7) geographic experiences affected their current attitudes, achievement, or awareness of geography. Like other research (Havorson \& Wescoat, 2002; SpronkenSmith, 2005), students' attitudes were only a portion of the study. The results of the research showed no overall correlation between childhood spatial activities and current attitudes towards geography (Alvarez, 1998). Both Havorson and Wescoat (2002) and Spronken-Smith (2005) studied problem-based learning in geography at the college 
undergraduate level. Although Havorson and Wescoat (2002) and Spronken-Smith's (2005) results included increasing positive attitudes towards geography through problembased learning instruction, the bulk of their research focused on content knowledge.

Baker and White (2003), Drennon (2005), Keiper (1999), and Tulloch and Graff (2007) also tested students' geographic attitudes. All of the studies used problem-based learning strategies while also including the use of Geographic Information Systems within the learning experience of their studies. All of the studies found that students' attitudes towards geography education improved through the use of these strategies. All four of the aforementioned studies failed to mention the reasons behind the increase in students' attitudes - problem-based learning strategy or the newly introduced technology, GIS.

Klein (1995) showed that problem-based learning also helps to increase students' attitudes and motivations in other ways. For example, Klein (1995) states that in order to "build feelings of empowerment... [in students, classroom activities should give] students an idea of what they can do to resolve local problems" (p. 366). Empowering students allows them to have a personal stake in their learning. By empowering students, problem-based learning can help to improve students' attitudes.

When problem-based learning instruction is created it must involve flexible lessons instead of rigid ones because students prove to be more wiling to learn when they have a choice (Shin, 2006). Geographic Information Systems creates choices for students by providing alternative ways to complete the same assignments, such as asking students to map man-made features in their hometowns. Some students might choose to map houses while others could pick fire hydrants, no parking signs, basketball hoops, or 
sidewalks. Students have chosen their features to map based on their interests, creating ownership of the assignments.

Problem-based learning also promotes the learning of other subjects, which can also improve students' attitudes (Tulloch \& Graff, 2007). Many students will not become geographers; however the skills they will learn through a problem-based learning environment will help them in many other areas (Tulloch \& Graff, 2007), such as English-Language Arts and Mathematics. Since problem-based learning does not solely focus on content knowledge, it requires students to use processes drawn from other subject knowledge to complete their work. For example, students will use Mathematics when examining population data and they will use English Language Arts skills while researching and writing up their findings.

\section{Group Work and Problem-Solving Efficacy}

This study will also examine students' preferences for group work and their problem-solving efficacy. Since problem-solving skills and the use of groups were so essential to problem-based learning instruction, they had the potential to impact the results of the study (Mergendoller et. al., 2006). However, Mergendoller, Maxwell, and Bellisimo (2006) did not any change to students' pretest and posttest in regards to preference for group work and students' problem-solving efficacy.

\section{Research Questions}

Education environments require more of an emphasis on problem-based learning, especially in geographic education, and significant research exists on its effectiveness to improve academic scores (Brickell \& Herrington, 2006; Havorson \& Wescoat, 2002;

Patterson et al., 2003; Tulloch \& Graff, 2007). However, a gap in the literature exists in 
interpreting the effect problem-based learning has on high school students' attitudes towards geography. More research needs to be conducted on the effect problem-based learning has on improving student attitudes towards geography (Walker, 2006). For these reasons the following questions need to be answered:

1. Does the introduction of problem-based learning positively improve high school students' attitudes towards geography?

2. Does the introduction of problem-based learning positively improve high school students' preferences towards working in a group?

3. Does the introduction of problem-based learning positively improve high school students' problem-solving efficacy?

4. Is there a correlational relationship between high school students' attitudes towards geography and preference for working in groups after problem-based learning instruction?

5. Is there a correlational relationship between high school students' attitudes towards geography and problem-solving efficacy after problem-based learning instruction? 


\section{CHAPTER III}

\section{METHODOLOGY}

\section{Introduction}

The purpose of this study was to determine the effectiveness of problem-based learning instruction on high school geography students' attitudes. The study interpreted three sections of a tenth grade introductory geography course. The students were given both pre- and post-surveys to determine their attitudes towards geography, preference for group work, and problem-solving efficacy.

\section{Sample}

The study interpreted the attitudes of three sections of Human Geography students throughout the entire term of the course. The term length was nine weeks taking place during the third term of the school year. This was the first and only geography course in the school district's curriculum.

The high school had an enrollment of 612 students (Illinois State Board of Education (ISBE), 2013) from six small agricultural based communities in central Illinois. Forty one percent of the entire high school population is defined as low-income (ISBE, 2013). Students at this school have an average ACT composite score of 21, which meets the state average in Illinois (ISBE, 2013). Students at this school were on a block schedule, meaning students take only four classes a term and meet 90 minutes per class. 
Forty-four tenth grade students were enrolled in the course and eligible to participate in the study. Of those students 17 are male and 27 female, 38 White/Caucasian, 3 Hispanic/Latino, 1 Black/African American, and 2 multiracial.

\section{Instrumentation}

Students were given one survey instrument twice, once at the beginning and once at the end of the course. The survey consisted of 31 items, organized into two sections. The first section of the survey determined students' attitudes towards geography. The instrument used, the Test of Geography-Related Attitudes (ToGRA) (Walker, 2006), a valid test "to determine students' attitudes towards geography" (p.179). The researcher obtained permission for use of this survey. This first section of the survey included all 29 questions from the ToGRA survey. The items were formatted using a five point Likert Scale ranging from 1, "Strongly Disagree" to 5, "Strongly Agree." The 29 items were categorized into attitudes about four areas of geography learning: enjoyment of geography (questions 1-7), career interest (questions 8-18), leisure interest (questions 1922), and interest in place (questions 23-29). The ToGRA had a coefficient alpha rating that ranged from 0.74 to 0.92 (Walker, 2006). The coefficient alpha rating for each category was- leisure (coefficient alpha rating of 0.74 ), enjoyment (0.88), career (0.92), and place (0.88). The coefficient alpha rating measures the internal consistency of the survey questions (Henson, 2001). The closer the alpha rating is to 1.0 the greater the internal consistency is, with an alpha of 0.8 as a "reasonable goal" (Gliem \& Gliem, 2003, p.87).

The second section of the survey contained two items. One measured student preferences for group work and the other measured problem-solving efficacy. For the 
second section, Mergendoller's et al. (2006) instrumentation was the source of the two items. The second section was used to increase this survey's reliability. The reasoning for including group work and problem-solving into this study is similar to the reasons outlined by Mergendoller et. al. Since problem-solving and the use of groups are so essential to problem-based learning instruction they could impact the results of the study (Mergendoller et. al., 2006). For example, if a student disliked group work they may have attributed that dislike of group work to a dislike of geography education. The opposite could happen if a student enjoyed group work and then responds favorably towards geography. Also, it is important to determine if students who preferred group work and felt that they were good problem-solvers had more positive attitudes towards geography as those students who saw themselves as poor problem-solvers and not preferring group work. The researcher obtained permission for use of these survey items. Both preferences for group work and problem-solving efficacy can influence the attitudes of students towards geography. These items helped to determine if poor problemsolving efficacy would lead to poor attitudes towards geography, or vice versa.

In terms of preference for group work, the survey contained an item with the prompt, "When I work with my classmates in small groups, I usually find that..." Four items followed this and students were asked to respond to Likert scale ranging from 1, "Strongly Disagree" to 5, "Strongly Agree." This survey item from which the item came is reliable with a coefficient alpha rating of 0.79 (Mergendoller et al., 2006). To determine problem-solving efficacy, students were asked: "I have difficulty solving problems when..." Students responded to five items on a Likert scale ranging from 1, "Strongly Agree" to 5, "Strongly Disagree." The scale was reversed to adjust for the 
negatively worded statement. From both of these final items, the scores were calculated by taking the mean response of all items. This survey item is reliable with a coefficient alpha rating of 0.82 (Mergendoller et al., 2006).

\section{Procedure}

A certified staff member, who was Collaborative Institutional Training Initiative (CITI) trained and was not affiliated with this research, administered the surveys, assent forms, and informative presentation where the administer also distributed consent letters to be sent home with the students for their parents to review and sign. The informative presentation and distribution of the consent forms took place on the first day of class. All participants who willingly agreed to participate in the study took the pre-survey on the fourth day of class. To ensure anonymity of the students' responses, a coding system was developed. Students selected their own identification number, which they recorded on an index card. The survey administrator recorded this number on the survey at collection. This number ensured that the analyzed data only included students who took both the preand post-surveys and that the proper pre- and post-surveys were compared with each other.

The course required students to solve real life problems through various projects. The projects asked students use skills in the process of problem-based learning. The course facilitated five problem-based learning projects: introduction to geographic questioning, World population and physiological density, World population pyramids, European Imperialism, and a final project. For the first project, introduction to geographic questioning, students selected a place of interest to research in the geographic perspective. Students used various skills including the geographic skills of asking 
geographic questions, acquiring geographic information, organizing geographic information, analyzing geographic information, and answering geographic questions (Heffron \& Downs, 2012) to determine why their place was where it was located. For both the World population and physiological density and World population pyramids projects students used the geographic skills acquiring geographic information, organizing geographic information, and analyzing geographic information along with various mathematical skills. Students collected, calculated, and analyzed population data to determine potential population problems. Students discussed solutions and career opportunities that would solve the problems they found. For the European Imperialism project students used the historical geographic perspective to learn about imperialism in Africa in the early $20^{\text {th }}$ century. Students drew before imperialism and after imperialism maps. The students used their prior knowledge from English classes, news programs, and major films to relate the maps to genocide problems facing Africa today. For the final project of the course, the instructor asked students to solve a real life problem facing the local community. The instructor used the instructional strategy problem-based learning to carry out this project. The project required students to create an emergency disaster plan for the community in which the high school is located. The problem was "illstructured" (Brickell \& Herrington, 2006; Havorson \& Wescoat, 2002; Stepien \& Gallagher, 1993) in that students did not have a set plan to follow or know exactly what they needed to do to create this plan. Students organized into groups, selected various disasters potential for the community, mapped the areas of concern, created a list of materials/resources needed, and presented their findings. Besides the instructor, the students communicated with various community members including the mayor, city 
council, fire chief, police chief, Red Cross volunteers, and city planners for the purpose of creating the city disaster plan.

At the completion of this project, on the final day of the course term, the survey administrator again distributed surveys for students to complete to disclose their attitudes towards geography, preference for working with groups, and problem-solving efficacy.

\section{Analysis}

Descriptive statistics including mean, standard deviation, and skewness were calculated along with correlation statistics. The researcher conducted t-test to test for the presence of significant differences between the pre- and post-survey means.

To answer research question one, does the introduction of problem-based learning positively increase high school students' attitudes towards geography, the researcher compared the sum of the means between students' pre- and post-surveys on questions 129 of the ToGRA (Walker, 2006) portion of the survey. To interpret the presence of change in subscales for question one, the comparisons between students' pre- and postsurveys using the following subscales were conducted: enjoyment of geography (questions 1-7), career interest (questions 8-18), leisure interest (questions 19-22), interest in place (questions 23-29), and overall attitudes (question 1-29).

To answer research question two, does the introduction of problem-based learning positively increase high school students' preference towards working in a group, the researcher employed descriptive analysis to compare means between students' pre and post surveys on questions 30a-30d (Mergendoller et al., 2006). Research question three, does the introduction of problem-based learning positively increase high school students' problem-solving efficacy, was answered using descriptive analysis that employed 
comparison of means between students' pre and post surveys using questions 31a-31d (Mergendoller et al., 2006).

To answer research questions four and five, is there a correlational relationship between high school students' attitudes towards geography, preference for working in groups, and problem-solving efficacy after problem-based learning instruction, the researcher employed a correlation analysis. The researcher determined if an association exists between students' attitudes towards geography, preference for working in groups, and problem-solving efficacy after problem-based learning instruction. The correlation analyses were conducted with the following variable pairings: first between geographic attitudes (questions 1-29) and preference for group work (questions 30a-d), and second between geographic attitudes (questions 1-29) and problem-solving efficacy (questions 31a-31d). 


\section{CHAPTER IV}

\section{RESULTS}

This research study examined the attitudes of students' towards geography before and after enrollment in a course taught using the instructional method problem-based learning. From the 44 students eligible to participate in this study, the researcher collected data from 40 students who completed and returned both parent consent and student assent forms. Of those 40 who participated, three completed only one survey and 10 completed both surveys but did not respond to all questions. Twenty-seven students completed both the pre- and post-survey with responses to all questions. The analysis included only the responses of these 27 students and analysis was performed in SPSS Statistics version 20.0 (IBM Corp., 2011). The following sections describe the statistical outcomes of the research study, organized by the research questions.

Question 1: Does the Introduction of Problem-based Learning Positively Improve High school Students' Attitudes towards Geography?

To answer this question, the researcher compared the means associated with the pre-survey with those associated with the post-survey on the first 29 survey questions. Descriptive statistics, mean, standard deviation and skewness, employed to interpret the central tendency, dispersion, and normalcy of the sample are presented in Table 1. 
Table 1

Students' Attitudes Towards Geography

\begin{tabular}{lrrrr}
\hline & Number & $M$ & SD & Skewness \\
\hline Pre Survey & 27 & 3.00 & .55 & .80 \\
Post Survey & 27 & 3.06 & .65 & .01 \\
Change & 27 & 0.06 & .36 & -.36 \\
\hline
\end{tabular}

The average mean score from the pre-survey $(M=3.00)$ increased during the postsurvey $(M=3.06)$ and resulted in a change of 0.06 . Students had a "neutral" attitude in both the pre- and post-survey. Student responses disbursed from the mean more during the post-survey $(\mathrm{SD}=0.65)$ then they did during the pre-survey $(\mathrm{SD}=0.55)$.

To determine whether a significant change in means from pre- to post-survey occurred, the researcher conducted a paired samples $t$ test. Results of this analysis are presented in Table 2. Results of the Levene's test were not significant, indicating homogeneity of variances between the two groups.

Table 2

Significance of Change in Students' Attitudes Towards Geography

\begin{tabular}{lrrr}
\hline & $t$ & $\begin{array}{r}\text { Degrees of } \\
\text { Freedom }\end{array}$ & $p$ \\
\hline Change in Geographic Attitudes & -.92 & 26 & .37 \\
\hline
\end{tabular}

The paired samples $t$ test did not show a significant difference between the means of the pre- and post-survey, $t(26)=-.918, p=.367$. The statistics indicate that students' attitudes towards geography did not significantly change after the introduction of problem-based learning. 


\section{Ancillary Analysis}

The researcher also compared the pre- and post-survey mean responses for the subscales: enjoyment of geography (questions 1-7), career interest (questions 8-18), leisure interest (questions 19-22), and interest in place (questions 23-29) of the ToGRA (Walker, 2006). The means presented are the average of all the students' means associated with survey items. Descriptive statistics, mean, standard deviation and skewness, employed to interpret the central tendency, dispersion, and normalcy of the sample are presented in Table 3. 
Table 3

Subscales of Students' Attitudes Towards Geography

\begin{tabular}{|c|c|c|c|c|}
\hline & Number & $M$ & SD & Skewness \\
\hline & \multicolumn{4}{|c|}{ Enjoyment of Geography } \\
\hline Pre Survey & 27 & 3.13 & .60 & 1.18 \\
\hline Post Survey & 27 & 3.24 & .61 & .32 \\
\hline \multirow[t]{2}{*}{ Change } & 27 & .11 & .42 & -.30 \\
\hline & \multicolumn{4}{|c|}{ Career Interest in Geography } \\
\hline Pre Survey & 27 & 3.06 & .51 & .27 \\
\hline Post Survey & 27 & 3.11 & .60 & -.61 \\
\hline \multirow[t]{2}{*}{ Change } & 27 & .05 & .45 & .08 \\
\hline & \multicolumn{4}{|c|}{ Leisure Interest in Geography } \\
\hline Pre Survey & 27 & 3.01 & .55 & .45 \\
\hline Post Survey & 27 & 3.02 & .82 & -.02 \\
\hline \multirow[t]{2}{*}{ Change } & 27 & .01 & .63 & -.80 \\
\hline & \multicolumn{4}{|c|}{ Interest in Place } \\
\hline Pre Survey & 27 & 2.80 & .70 & .68 \\
\hline Post Survey & 27 & 2.88 & .77 & .15 \\
\hline Change & 27 & .08 & .48 & .41 \\
\hline
\end{tabular}

The mean score for each subscale increased from the pre-survey to the post-survey, however a paired samples $t$ test did not find the change in means to be significantly different (Table 9, Appendix B). 
Question 2: Does the Introduction of Problem-based Learning Positively Improve High school Students' Preferences towards Working in a Group?

To answer this question, the researcher compared the means associated with the pre-survey with those associated with the post-survey on questions 30a -30d. Descriptive statistics, mean, standard deviation and skewness, employed to interpret the central tendency, dispersion, and normalcy of the sample are presented in Table 4.

Table 4

Students' Preference Towards Group Work

\begin{tabular}{lrrrr}
\hline & Number & $M$ & \multicolumn{1}{c}{ SD } & Skewness \\
\hline Pre Survey & 27 & 3.80 & .81 & -1.41 \\
Post Survey & 27 & 3.80 & .81 & -.39 \\
Change & 27 & .00 & .84 & .72 \\
\hline
\end{tabular}

The average mean score from the pre-survey $(M=3.80)$ to the post-survey $(M=3.80)$ did not change $(M=0.00)$. The research has shown that students' preference for working in groups does not change after problem-based learning instruction.

Question 3: Does the Introduction of Problem-based Learning Positively Improve High school Students' Problem-solving Efficacy?

To answer this question, the researcher compared the means associated with the pre-survey with those associated with the post-survey on the final four survey questions.. Descriptive statistics, mean, standard deviation and skewness, employed to interpret the central tendency, dispersion, and normalcy of the sample are presented in Table 5. The mean score from the pre-survey $(M=2.90)$ to the post-survey $(M=3.02)$ had a change of 0.12 . 
Table 5

Students' Problem Solving Efficacy

\begin{tabular}{lrrrr}
\hline & Number & $M$ & SD & Skewness \\
\hline Pre Survey & 27 & 2.90 & .62 & .69 \\
Post Survey & 27 & 3.02 & .77 & .62 \\
Change & 27 & .12 & .63 & .05 \\
\hline
\end{tabular}

To determine whether a significant change in means from pre- to post-survey occurred, the researcher conducted a paired samples $t$ test. Results of this analysis are presented in Table 6. Results of the Levene's test were not significant, indicating homogeneity of variances between the two groups.

Table 6

Significance of Change in Students' Problem Solving Efficacy

\begin{tabular}{lccc}
\hline & $t$ & $\begin{array}{r}\text { Degrees of } \\
\text { Freedom }\end{array}$ & $p$ \\
\hline Change in Problem Solving Efficacy & -.99 & 26 & .33 \\
\hline
\end{tabular}

The paired samples $t$ test did not show a significant change between the means of the preand post-survey, $t(26)=-.994, p=.329$. The statistics indicate that students' attitudes towards problem solving efficacy did not significantly change after the introduction of problem-based learning. 
Question 4: Is there a Correlational Relationship Between High school Students' Attitudes towards Geography and Preference for Working in Groups after Problembased Learning Instruction?

To answer this question, the researcher performed a correlation analysis between the students' responses to geographic attitudes and preference for group work for both pre- and post-surveys. Pearson Correlation ( $r$ value) and Sig. (2-tailed), employed to determine significance of the relationship are presented in Table 7. The statistics indicate that there is no significant correlational relationship between geographic attitudes and preference for group work before or after the course.

\section{Table 7}

Relationship Between Students' Geographic Attitudes and Preference for Group Work

\section{Pre Survey}

Preference for Group Work

\begin{tabular}{clr}
\hline \multirow{2}{*}{$\begin{array}{c}\text { Peographic } \\
\text { Attitudes }\end{array}$} & Sig. (2-tailed) & -.15 \\
& Number & .45 \\
& & 27 \\
\hline \multirow{2}{*}{ Post Survey } & \\
& & Preference for Group Work \\
\hline \multirow{2}{*}{ Geographic } & Pearson Correlation & .01 \\
Attitudes & Sig. (2-tailed) & .98 \\
& Number & 27 \\
\hline
\end{tabular}


Question 5: Is there a Correlational Relationship Between High school Students' Attitudes towards Geography and Problem-solving Efficacy after Problem-based

\section{Learning Instruction?}

To answer this question, the researcher performed a correlation analysis between the students' responses to geographic attitudes and problem-solving efficacy for both preand post-surveys. Pearson Correlation ( $r$ value) and Sig. (2-tailed), employed to determine significance of the relationship are presented in Table 8. The statistics indicate that there is no significant correlational relationship between geographic attitudes and problem solving efficacy before or after the course.

Table 8

Relationship Between Students' Geographic Attitudes and Problem Solving Efficacy

\section{Pre Survey}

\begin{tabular}{clr} 
& & Problem Solving Efficacy \\
\hline \multirow{2}{*}{$\begin{array}{c}\text { Geographic } \\
\text { Attitudes }\end{array}$} & Pearson Correlation & .24 \\
& Sig. (2-tailed) & .22 \\
& Number & 27 \\
\hline & & \\
& & Post Survey \\
Geographic & Pearson Correlation & .21 \\
Attitudes & Sig. (2-tailed) & .29 \\
& Number & 27 \\
\hline
\end{tabular}




\section{CHAPTER V \\ DISCUSSION}

\section{Introduction}

The research study found no significant change in high school students' geographic attitudes, preference for group work, or problem-solving efficacy before and after enrollment in a geography course taught using the problem-based learning instructional method. The results also failed to show any significant correlational relationship between students' geographic attitudes, preference for group work, or problem-solving efficacy. The following chapter sections contain the researcher's thoughts about the possible causes of the results. Patterns of learning in schools were the first possible cause examined. The topics of teacher verses student training in problembased learning, break from teacher-centered industrialist model classroom, and high stakes testing are all discussed. Next, the lack of geographic education as a possible cause for no change in the results is explored. Finally the researcher provides a discussion of the limitations of this study.

\section{Patterns of Learning in Schools}

Problem-based learning requires both teachers and students to take on different roles in the classroom (Mergendoller et al., 2006; Stepien \& Gallagher, 1993; Tulloch \& Graff, 2007). Although teachers prepare for these different roles through professional development and curriculum planning, students on the other hand 
must adjust to new learning strategies as the course progresses. The researcher limited the study to only collect quantitative data. This did not allow the researcher to collect or interpret students' observed responses to the experience, thus limited conclusions are possible from survey responses.

A student-centered approach such as problem-based learning challenges the industrialist model classroom that students typically experience. Brantlinger (2013, 2014) researched mathematical reform and found that a break from teacher-centered industrialist model instructional strategies led students to resist and become unengaged in classroom activities. In the case of Brantlinger, students appeared to lessen resistance as the course progressed. However, it could be the early resistance that influenced students to not respond higher on their post surveys.

Problem-based learning is a new instructional strategy in the discipline of Geography (Pawson et al., 2006; Spronken-Smith, 2005). The National Geography Standards (Heffron \& Downs, 2012) include a focus on "Doing Geography” which emphasizes the problem-based learning philosophy. Teachers experience difficulties implementing such instructional approaches in their classrooms. According to Vogler and Virtue (2007) "teachers under the pressure of high stakes [testing] tend to use teacher-centered instructional practices, such as lecture, instead of student-centered approaches" (p.56). That may be explained by schools accountability to standardized testing (Mitchell, 2009). Even though social studies is not tested, social studies teachers feel pressure to change their teaching strategies to match their colleagues in tested departments (Vogler \& Virtue, 2007). 
This current study examined only one of the four courses students take daily. It is possible that students may be hesitant to accept problem-based learning when it does not reflect the majority of their course work. The lack of exposure to student-centered approaches may be a possible explanation for why the results also failed to show any change in or a correlational relationship between students' geographic attitudes, preference for group work, and problem-solving efficacy. Students may have resisted the change from the teacher-centered industrialist classrooms. The results of this study are consistent with Mergendoller et al. (2006) whereas no significant change was found in preference for group work or problem-solving efficacy after a course taught with problem-based learning instructions. Mergendoller's et al. explanation is that the lack of exposure to group work and problem-solving in teacher-centered classrooms may influence students' survey responses. Students may have thought about their experiences in teacher-centered classrooms when responding to survey questions about group work and problem solving.

\section{Lack of Geographic Education}

Later in this section differences in student attitudes related to the survey are explored. Another plausible explanation for the nominal changes in means is that students may enter this course without biases about the subject. Also students could enter the course after discussing it with other students that have taken the course previously and their attitudes do not change from talking to their peers through enrollment in the course. If this research was performed during the first term of the school year, it may eliminate that factor. 
The short length of the course could be an important cause for the lack of attitudinal change. Other research (Brantlinger, 2013, 2014; Mergendoller et al., 2006) has pointed to length of study as a plausible cause for unchanged attitudes about learning. A course held over a school year may be more appropriate for this study so that the learning outcomes can be measured after problem-based learning instruction can take full effect.

\section{Limitations}

The study was limited to a quantitative instrument. Students' "neutral" responses may be explained because students felt limited in their choices of responses or that the responses did not reflect how they felt. Being unsure of how to respond may have led students to stay neutral in their answers on the survey questions. A quantitative study does not allow the participants to fully express their feelings or attitudes, but rather the participant is limited to the choices on the survey. The "neutral" response could also be explained because of the use of a five-point scale on the survey. A four-point scale would have forced students to decide if they agreed of disagreed.

Through selection of the instrumentation, the researcher sought a tool that had been tested to be valid. The researcher did not make any adjustment to the wording of questions, placement of questions, or the number of questions. In reflecting upon this decision, some of the questions used from ToGRA (Walker, 2006) were inappropriate for the age group tested because technology has changed since the ToGRA's creation eight years ago. For example, question twelve states "I enjoy listening to radio programs about different people and places." If one looked at only the responses to question twelve, the most frequent response was a 2 (disagree). One must ask, do students disagree with 
enjoying listening about geography or do they disagree with the statement about listening on a radio. The researcher would reason that students may not listen to the radio, especially as we are in the age of podcast, MP3 player, iPods, and iPhones.

Had the study included a qualitative aspect, the results may have clarified the statistical findings. Participants may have been more open to share positive experiences and outcomes in an open-ended question format. Students may not have been that excited to take the survey or were unsure how to put a number to their feelings. The instrument was designed for use in secondary geography classrooms, but a larger sample is needed to fully explore statistical patterns and clarify findings. Future studies should employ qualitative and quantitative methods to record participants' personal responses about the class both before and after enrollment. 


\section{CHAPTER VI}

\section{CONCLUSION}

\section{Conclusion and Implications}

This study found that students' attitudes towards geography, preference for group work, and problem-solving efficacy did not significantly change with the use of problembased learning instruction. Also, the study found that there was no significant correlational relationship between students' geographic attitudes and preference for group work or problem-solving efficacy.

Problem-based learning is indicated to be an effective instructional strategy for improving students' geographic content knowledge (Brickell \& Herrington, 2006; Havorson \& Wescoat, 2002; Patterson et al., 2003; Tulloch \& Graff, 2007). As geography educators try to move to a more student-centered approach (Brickell \& Herrington, 2006; Havorson \& Wescoat, 2002; Pawson, et al., 2006; Spronken-Smith, 2005; Tulloch \& Graff, 2007) they fight standardized testing used to measure student achievement (Vogler \& Virtue, 2007). Common Core State Standards for EnglishLanguage Arts and Mathematics provide hope for change in instructional strategies used in social studies classrooms. However, the continued use of standardized testing makes change difficult especially in tested classrooms. The difficulty is that educators in tested classrooms continue to have to prepare students for high stakes tests. Social studies 
educators have an opportunity to be the bridge between the tested content and the real world problems faced everyday. If this can be accomplished, social studies educators may be able improve students' attitudes towards social studies. Increases in attitudes towards the subject result in higher achievement (Walker, 2006) but more importantly, go beyond achievement and students become more engaged citizens.

\section{Recommendations for Future Research}

Further research needs to be conducted on the topic of geographic attitudes in educational settings. The topic of geographic attitudes continues to be an understudied topic. Future studies should include an instrument that measures geographic attitudes in problem-based learning instruction as well as other instructional strategies. Other instructional strategies should be included to determine the best methods for improving students' attitudes towards geography. The outcomes of this study make more research on geographic attitudes and problem-based learning important. Research on geographic attitudes and instructional strategies should be explored with the use of both quantitative and qualitative aspects. Future researchers should study a geography course over an entire school year or study a school setting that has a stronger problem-based learning curriculum.

As schools enter the world of Common Core State Standards educators have many decisions to make. More research needs to be done on the best methods to teach the non-Common Core classes such as geography. There is an opportunity for educators and school districts to create change in curriculum that best fits the needs of their students. 


\section{REFERENCES}

Alvarez, K. (1998). The relationship between early childhood geographic activities and achievement in, attitude toward, and awareness of geography (Doctoral dissertation). Retrieved from ProQuest Dissertations and Theses.

Aydin, F. (2011). Secondary school students' opinions about geography course: A qualitative study. Archives of Applied Science Research, 3(1), 297-305.

Baker, T., \& White, S. (2003). The effects of G.I.S. on students' attitudes, self-efficacy, and achievement in middle school science classrooms. Journal of Geography, 102(6), 243-254.

Bednarz, S. (2004). Geographic information systems: A tool to support geography and environmental education? GeoJournal, 60, 191-199.

Bednarz, S., Bettis, N., Boehm, R., De Souza, A., Downs, R., Marran, J., Morrill, J., Salter, C. (1994). Geography for life: National geography standards $1994\left(1^{\text {st }}\right.$ ed.). Washington, D.C.: National Geographic Research \& Exploration.

Béneker, T., Sanders, R., Tani, S., Taylor, L., \& van der Vaart, R. (2007). Teaching the geographies of urban areas: Views and visions. International Research in Geographical and Environmental Education, 16(3), 250-267.

Bradbeer, J., Healey, M., \& Kneale, P. (2004). Undergraduate geographers' understanding of geography, learning and teaching: A phenomenographic study. Journal of Geography in Higher Education, 28(1), 17-34.

Brantlinger, A. (2013). Between politics and equations: teaching critical mathematics in a remedial secondary classroom. American Educational Research Journal, 50(5), 1050-1080.

Brantlinger, A. (2014). Critical mathematics discourse in a high school classroom: Examining patterns of student engagement and resistance. Educational Studies In Mathematics, 85, 201-220.

Brickell, G., \& Herrington, J. (2006). Scaffolding learners in authentic, problem based elearning environments: The geography challenge. Australasian Journal of Educational Technology, 22(4), 531-547. 
Council of chief state school officer and national governors association. (2010). Common Core Standards for English Language Arts \& Literacy in History/Social Studies, Science, and Technical Subjects. Retrieved November 3, 2013, from Illinois State Board of Education: http://www.isbe.net/common_core/pls/level1/pdf/elastandards.pdf

Drennon, C. (2005). Teaching geographic information systems in a problem-based learning environment. Journal of Geography in Higher Education, 29(3), 385402.

Duch, B., Groch, S., \& Allen, D. (Eds.) (2001). The power of problem-based learning $\left(1^{\text {st }}\right.$ ed.). Sterling, VA: Stylus Publishing.

Gliem, J., \& Gliem, R. (2003, October). Calculating, interpreting, and reporting Cronbach's alpha reliability coefficient for likert-type scales. Paper presented at the Midwest Research-to-Practice Conference in Adult, Continuing, and Community Education, Columbus, $\mathrm{OH}$.

Havorson, S., \& Wescoat, J. (2002). Problem-based inquiry on world water problems in large undergraduate classes. Journal of Geography, 101(3), 91-102.

Heffron, S., \& Downs, R. (Eds.) (2012). Geography for life: National geography standards $\left(2^{\text {nd }}\right.$ ed.). Washington D.C.: National Council for Geographic Education.

Henson, R. (2001). Understanding internal consistency reliability estimates: A conceptual primer on coefficient alpha. Measurement and Evaluation in Counseling and Development, 34(3), 177-189.

IBM Corp. (2011). SPSS Statistics for Macintosh (Version 20.0) [Computer software]. Armonk, NY: IBM Corp.

Illinois State Board of Education (2013). School snapshot: Prairie Central High School. Retrieved January 27, 2014, from http://iirc.niu.edu/School.aspx?schoolId=170530080260001

Jonassen, D. (2000). Towards a design theory of problem solving. Educational Technology Research \& Development, 48(4), 63-85.

Keiper, T. (1999). GIS for elementary students: An inquiry into a new approach to learning geography. Journal of Geography, 98(2), 47-59.

Klein, P. (1995). Using Inquiry to enhance the learning and appreciation of geography. Journal of Geography, 94(2), 358-367. 
Mergendoller, J., Maxwell, N., \& Bellisimo, Y. (2006). The effectiveness of problembased instruction: A comparative study of instructional methods and student characteristics. Interdisciplinary Journal of Problem-based Learning, 1(2), 4969.

Mitchell, J. (2009). Hazards education and academic standards in the Southeast United States. International Research in Geographical and Environmental Education, 18(2), 134-148.

National Research Council (2006). Learning to think spatially. Washington, D.C.: The National Academies Press.

Patterson, M., Reeve, K., \& Page, D. (2003). Integrating geographic information systems into the secondary curricula. Journal of Geography, 102(6), 275-281.

Pawson, E., Fournier, E., Haigh, M., Muniz, O., Trafford, J., \& Vajoczki, S. (2006). Problem-based learning in geography: Towards a critical assessment of its purpose, benefits and risks. Journal of Geography in Higher Education, 30(1), $103-116$.

Shin, E. (2006). Using geographic information system (GIS) to improve fourth graders' geographic content knowledge and map skills. Journal of Geography, 105(3), 109-120.

Songer, L. (2010). Using web-based GIS in introductory human geography. Journal of Geography in Higher Education, 34(3), 401-417.

Spronken-Smith, R. (2005). Implementing a problem-based learning approach for teaching research methods in geography. Journal of Geography in Higher Education, 29(2), 203-221.

Stepien, W., \& Gallagher, S. (1993). Problem-based learning: As authentic as it gets. Educational Leadership, 50(7), 25-28.

Tulloch, D., \& Graff, E. (2007). Green map exercises as an avenue for problem-based learning in a data-rich environment. Journal of Geography, 106(6), 267-276.

Vogler K., \& Virtue D. (2007). "Just the facts, ma'am": Teaching social studies in the era of standards and high-stakes testing. The Social Studies, 98(2), 54-58.

Walker, S. (2006). Development and validation of the Test of Geography-Related Attitudes (ToGRA). Journal of Geography, 105(4), 175-181. 
APPENDIX A

\section{PARTICIPANT SURVEY}




\section{Survey}

Directions

This survey contains statements about what you think about geography, working in groups, and your confidence in solving problems. There are no right or wrong answers. Your opinion is what is wanted.

For each statement, place an "X" in the box that best fits your response.

Some statements in this survey are very similar, please indicate your opinion for each statement.

\begin{tabular}{|c|c|c|c|c|c|}
\hline & 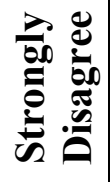 & 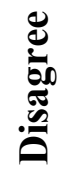 & 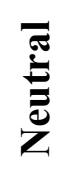 & 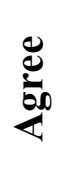 & 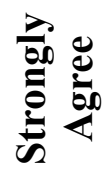 \\
\hline 1. Geography lessons are fun. & & & & & \\
\hline $\begin{array}{l}\text { 2. I would like to be a geographer after I leave } \\
\text { school. }\end{array}$ & & & & & \\
\hline 3. I enjoy looking at maps and globes. & & & & & \\
\hline 4. I like studying geography. & & & & & \\
\hline $\begin{array}{l}\text { 5. When I graduate from school I would like to work } \\
\text { with people who do geography. }\end{array}$ & & & & & \\
\hline 6. I like to read about different people and places. & & & & & \\
\hline 7. School should have more education in geography. & & & & & \\
\hline $\begin{array}{l}\text { 8. I would like a job doing geography after I leave } \\
\text { school. }\end{array}$ & & & & & \\
\hline 9. I like to talk about different people and places. & & & & & \\
\hline 10. I enjoy studying about people and places. & & & & & \\
\hline $\begin{array}{l}\text { 11. Working as a geographer would be an interesting } \\
\text { way to earn a living. }\end{array}$ & & & & & \\
\hline $\begin{array}{l}\text { 12. I enjoy listening to radio programs about different } \\
\text { people and places. }\end{array}$ & & & & & \\
\hline $\begin{array}{l}\text { 13. Geography is one of the most interesting subjects } \\
\text { in school. }\end{array}$ & & & & & \\
\hline $\begin{array}{l}\text { 14. A career in geography would be interesting and } \\
\text { exciting }\end{array}$ & & & & & \\
\hline $\begin{array}{l}\text { 15. I like to read newspaper articles about other } \\
\text { places. }\end{array}$ & & & & & \\
\hline 16. Geography lessons are worth my time. & & & & & \\
\hline $\begin{array}{l}\text { 17. I would like to teach geography when I leave } \\
\text { school. }\end{array}$ & & & & & \\
\hline 18. I prefer to use maps when inquiring about places. & & & & & \\
\hline 19. I really enjoy lessons about people and places. & & & & & \\
\hline 20. A job that uses maps would be exciting. & & & & & \\
\hline
\end{tabular}




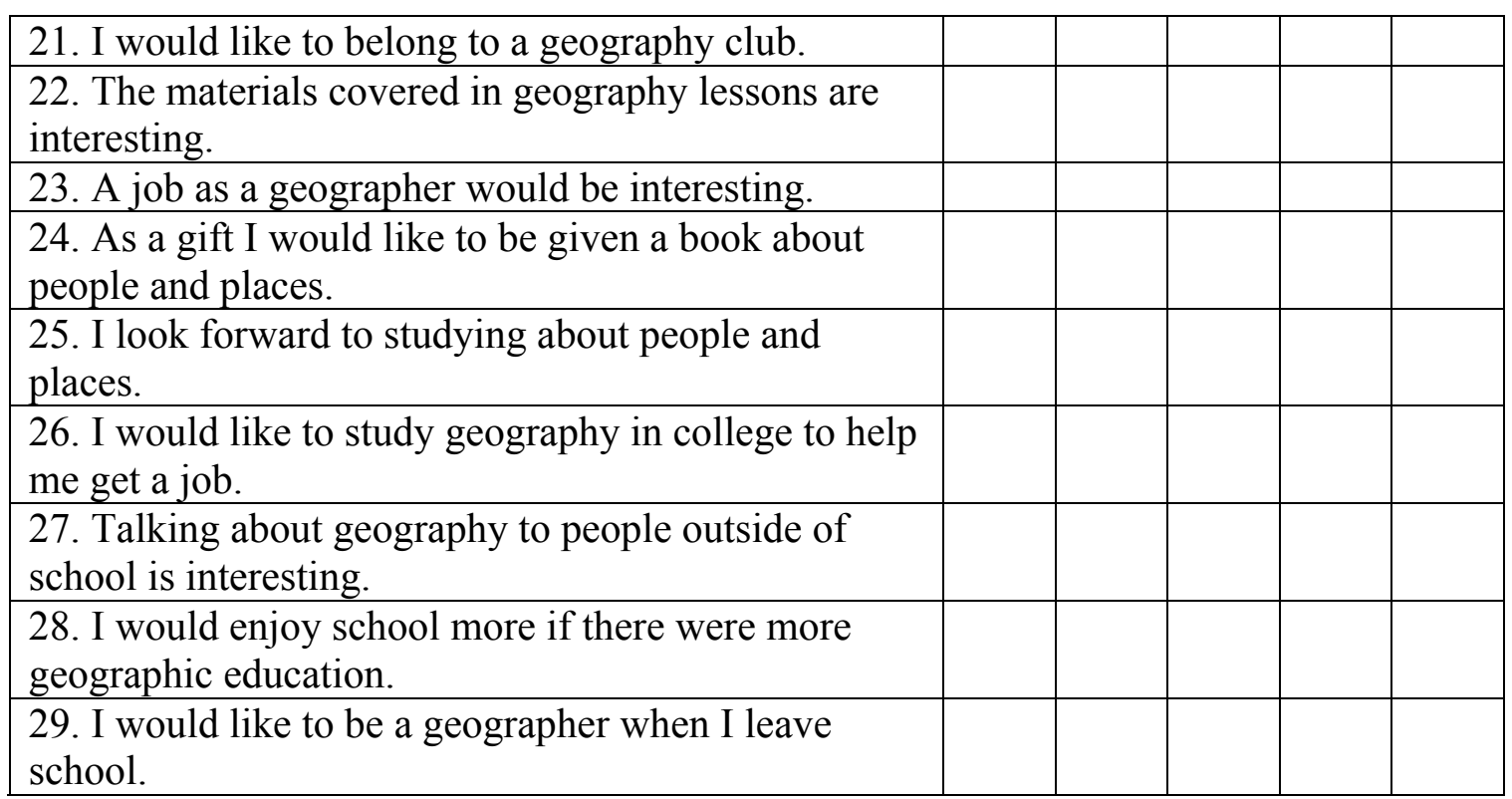

(C) 2004-2014 Scott L. Walker, Used with permission.

\begin{tabular}{|c|c|c|c|c|c|}
\hline $\begin{array}{l}\text { 30. When I work with my classmates in small } \\
\text { groups, I usually find that... }\end{array}$ & 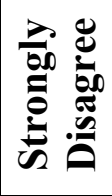 & 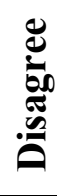 & 矛 & 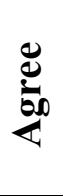 & 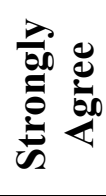 \\
\hline \multicolumn{6}{|l|}{ a. it helps me learn. } \\
\hline \multicolumn{6}{|l|}{$\begin{array}{l}\text { b. it gives me a new way to think about what we are } \\
\text { studying. }\end{array}$} \\
\hline \multicolumn{6}{|l|}{$\begin{array}{l}\text { c. I learn more in the small groups than I do from } \\
\text { class activities I do by myself. }\end{array}$} \\
\hline d. it is an excellent way to study for test. & & & & & \\
\hline
\end{tabular}

\begin{tabular}{|c|c|c|c|c|c|}
\hline 31. I have difficulty solving problems when... & 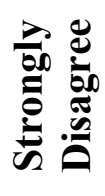 & 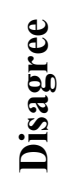 & 茪 & 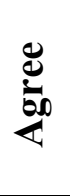 & 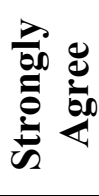 \\
\hline a. I have to find my own resources and information. & & & & & \\
\hline b. I have to argue my own point of view. & & & & & \\
\hline c. other people disagree with me. & & & & & \\
\hline d. I have to defend my choice. & & & & & \\
\hline
\end{tabular}


APPENDIX B

TABLE 9: SIGNIFICANCE OF CHANGE IN SUBSCALES OF STUDENTS' ATTITUDES TOWARDS GEOGRAPHY 
Table 9

Significance of Change in Subscales of Students' Attitudes Towards Geography

\begin{tabular}{lrrr}
\hline & $t$ & $\begin{array}{r}\text { Degrees of } \\
\text { Freedom }\end{array}$ & $p$ \\
\hline Change in Enjoyment of Geography & -1.36 & 26 & .19 \\
Change in Career Interest in Geography & -.63 & 26 & .54 \\
Change in Leisure Interest in Geography & -.08 & 26 & .94 \\
Change in Interest in Place & -.86 & 26 & .39 \\
\hline
\end{tabular}

